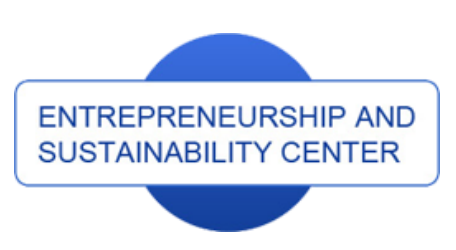

Publisher

http://jssidoi.org/esc/home

http://doi.org/10.9770/jesi.2017.5.2(4)

\title{
MANAGEMENT TEAM DEVELOPMENT OPPORTUNITIES: A CASE OF LITHUANIAN FURNITURE COMPANY
}

\author{
Algirdas Giedraitis ${ }^{1}$, Rimantas Stašys ${ }^{2}$, Rita Skirpstaité ${ }^{3}$ \\ ${ }^{1,2,3}$ Klaipéda University, Minijos str. 153, 93185 Klaipéda, Lithuania \\ E-mails: ${ }^{1}$ giedraitis.algirdas@gmail.com; ${ }^{2}$ rimantas.stasys@ku.lt; ${ }^{3}$ ritaskirpstaite@gmail.com
}

Received 13 June 2017; accepted 26 September; published 29 December 2017

\begin{abstract}
The accelerating implementation of innovations in business "drags" the enterprise management teams into a chain of constant changes which requires rapid adaptation to the process of changes, becoming a routine. Development as an issue of a systemic qualitative change and of the increasing internal organisational potential is one of the most important issues in the advancement of modern organisations. The article introduces to the opportunities of the management team development as one of the main activity trends seeking to ensure the possibility of successful team management, continuous improvement of the members, and increasing competitiveness of the organisation. Upon conducting qualitative research in a Klaipeda region furniture manufacturing company, its findings, i. e. the opportunities of the management team development are presented: to encourage all the members of the management team to become leaders; to identify the goals of the personality and the competences development; to find out which competences each member wants to improve and to allow them to undertake additional activities that would enable the improvement of those competences; to set the operational goals for the members which would also allow (help) them to pursue their personal goals; to coordinate the values of the organisation and the team members on the basis of needs, when the need for self-realisation prevails over their hierarchy; to give more responsibility to the team members who wish and seek it; and to authorise each member of the team to resolve comnflicts independently.
\end{abstract}

Keywords: production company, management team, development

Reference to this paper should be made as follows: Giedraitis, A.; Stašys, R.; Skirpstaite, R. 2017. Development possibilities of the management team within a production company, Entrepreneurship and Sustainability Issues 5(2): 212-222. http://doi.org/10.9770/jesi.2017.5.2(4)

JEL Classifications: M12

Additional disciplines: psychology; educology

\section{Introduction}

The accelerating implementation of innovations in business "drags" the enterprise management teams into a chain of constant changes which requires rapid adaptation to the process of changes, turning into a routine. The aspiration of enterprises to exist today and to remain in the future is inseparable from consistent work in the formation and development of management teams whose successful performance depends on the potential and skills of their members and their desire to constantly improve. Therefore, every member of the team has to be encouraged to constantly analyse their experience and prospects and to transform the obtained data to pursue the management team development goals. The activity of the management team is related to such outcomes as the growth of the income, market share, and profitability. 
As a rule, researchers agree that the main hindrances in the management team development are inside the organisation. If the management team is not developed, there is no use talking about its spontaneous development, as the team cannot develop by itself, without an artificial stimulus. It is very importanty to identify and remove the hindrances, since the internal potential with a stimulus and without hindrances promotes development and helps each member of the management team to reveal their potential. In that way, the potential of each manager increases, and the synergistic effect is strengthened among the members of the team; and that is the key to success, innovation, and creativity (Smith, 2006). Since most authors have different perceptions of the prerequisites and goals of the management team development, the process of the management team development has not been sufficiently described, and its further research issues remain relevant.

Scientific problem: the developmental opportunities of the management team have not been adequately addressed in scientific literature and have not been proved in practice.

Research object: the management team in a production company.

Research aim: to establish the opportunities for the management team development in a production company.

The objectives: to identify the key elements in the production team development and to establish the opportunities for the management team development in a production company.

Methodology. In order to identify the key elements in the management team development, the method of a systemic analysis of scientific literature was applied, and to establish the opportunities of the management team development in a production company, a qualitative research method - a semi-structured interview was chosen. The research participants- informants were 8 managers of all levels. The research was carried out in a furniture manufacturing company in Klaipèda region in April 2016.

\section{A theoretical model of the management team development}

As defined by V. Diska and A. Marčinskas (2013), a manager is an employee who is able to make decisions within his area of competence in different fields of activity of the team entrusted to him, responsible for the performance of the entrusted division and exerting influence upon the entrusted team by specific management instruments. The situation of each manager in a company is different due to the difference in the number of subordinates, the area of management, the position occupied in the structure of the company, and the stage of the company's development (Staniulienè, 2008).

In the performance of management functions by top-level managers, the emphasis on leadership ought to be evident, as it is related to having a vision, the ability to model, and a broad approach to the developing phenomena. Middle-level managers need more administrative abilities, as they accept the role of mediators, i. e. get the tasks formulated by higher authorities and distribute them to their subordinates. In such cases, the managers do not need to have any special creativity, and they do not create future visions. They only pass instructions and control how these are executed. The role of an administrator ought to be combined with leadership: such a manager ought to motivate employers for productive work and increase their involvement in the company's activity. A manager-administrator is also necessary at the low level of management, where the technical skills are the most important.

Each manager in any enterprise, from the top to the low level, has to have clear aims which should support the goals of the managers of the higher hierarchical levels of management (Zakarevičius, 2003). Both the ability of the team to realise the possessed potential and the efficiency of the company depend on the optimality of the management team of the company. Such a management team has greater interoperability. 
ENTREPRENEURSHIP AND SUSTAINABILITY ISSUES

ISSN 2345-0282 (online) http://jssidoi.org/jesi/

2017 Volume 5 Number 2 (December)

http://doi.org/10.9770/jesi.2017.5.2(4)

In order to establish the elements of the management team development complex, it is important to define the concept of the team. To quote S. Raižienè, A. Endriulaitienè (2007) and I. Beniušienè, J. Vveinhardt, G. Merkys, M. Dromantas (2005), a team is a small group of people whose knowledge and experience complement one another in the pursuit of a common goal. In accordance to R. Hirschfeld et al. (2006), a team is a structured group of people who interact in the achievement of the goals and certain objectives set for collective performance. The team must ensure the implementation of the strategy and appropriate conditions that enable purposeful use of all the possessed resources in order to achieve the company's efficiency and success (West, 2012). The members of the team must be responsible not only for themselves, but also for the other members of the team.

Of all the individual's capabilities and qualities, development is the most important. The development of the management team is inseparable from the development of the potential of each team member and of the relationships between the team members. When the potential of each team member increases, combined with the strengthening of the relations between employees and due to the synergy effect, the results of the company's activity will increase proportionately. Development is a process which includes self-awareness and selfobservation, identification of strengths and weaknesses, an individual-initiated desire to change, long-term commitment to change, the onset of change, and the recognition of a potential failure. Therefore, the following formula of the management team members' development can be proposed (Kvedaravičius, 2006):

$$
\mathrm{P} \text { of the management team }=\Sigma \mathrm{P} \text { of the team members }+\Sigma \mathrm{R} \text { of the team members }+\Delta \mathrm{S} \text { of the management team, }
$$

where $\mathbf{P}$ is potential, $\mathbf{R}$ is relationships, and $\mathbf{S}$ is the synergistic effect.

The resources for manager's development lie in the individual himself, however, a development-friendly milieu is necessary, i. e. a team. The management team will only develop when each member of the team develops. A manager's desire for development must come from the inside, the team cannot make him change, however, the team can provide development-friendly conditions when the members of the management team face new challenges, are encouraged to improve, and can reveal their inner potential.

B. Tuckman in 1965 proposed the first group development model. He said that four phases (forming-stormingnorming-performing) are all necessary and inevitable in order for the team to grow, face up to challenges, tackle problems, find solutions, plan work, and deliver results. However, the model proposed by him changed, as the development of a management team is an artificially natural process of a sociocultural system where the internal qualitative potential is acquired by the team members mastering the new and improving the old competences in order to more effectively work in and for the company.

The management team must first of all have an examplary head of the team, i. e. leader. The mission of the management team leader is to get together the best team and help it achieve its goals. He needs to get together an effective, hard working team, to be able to promote its creative potential, to skillfully manage the emerging conflicts, and to solve problems. The leader must have clear activity goals and evaluation criteria, to promote the company's development, and to know and stimulate the team members (Drucker, 2009; Kasiulis, Barvydiené, 2004). The leader shares the position of leadership with all the team members. In each situation, the management team is to have a leader who best performs certain functions. However, the managers' potential of leadership is not sufficient yet, and that frequently becomes a significant obstacle to the further development of the company.

Competences are the basis of teamwork, therefore, the members of the management team have to have different competences. Each member of the management team has to share his own competences and to be able to make use of the competences of other team members. The "mix" of the competences of the management team members is the combination of the pursuit of the set goals (Savanevičienè ir kt., 2008; Žydžiūnaitė, 2003; Robbins, 2003). All the forms of activity (knowledge, abilities, and skills) never become values by themselves until the team member gives prominence to them, provides them with significance, and relates them to his own experience. 
The management team ought to choose members who are energetic, enjoy active work, cope with their emotions, and are ready to openly express their opinion. The team members are to be highly motivated and seek to improve and to be leaders. Every team member has to have a possibility to improve. Innovation formation and implementation has to be a continuous and dynamic process (Misevičius, Urbonienė, 2006; Robbins, 2003; Dlugoborskyte et al., 2015). It is especially important to promote the creative productivity of activity. Without a material "basis", the management team tends to act without any plan and spontaneously respond to the requirements of the environment (customers or consumers). Their priority becomes the ensuring of the minimal level financial resources needed to maintain the company and its employees, and they move away from the implementation of the company's mission and goals.

The management team members have to understand the team's goals and to seek their compatibility. Wellbalanced goals bring positive results to the team amd team members. The goals of the team members have to be clearly defined and comply with their competences (Diska, Marčinskas, 2013; Jezerskytė, Žydžiūnaitė, 2005; Yuen, 2004). The goals and objectives of the company keep changing, and depending on that, the roles of the management team members may change, too. The management team is characterised by unity, as only interrelated team members affect one another; the presence of all the team members is necessary for the implementation of a common goal and for meeting individual needs of each member. The failure to properly convey the goal may lead to a number of management problems. The ambiguity of the goal causes the employees' tension, uncertainty, dissatisfaction, and confusion. A poor result is obtained when the goals of the company change, and the employees' expectations do not; when the goals of the company do not change, and the employees' expectations do; or when the goals of the company and the employees' expectations do not change or change too late.

The compatibility of the leader's personal values with the values and standards of other team members and the company as a whole has a positive impact on the employees' emotional commitment to the company and stimulates their wish to stay in it. The compatibility of the values of the company, team, and each team member is possible when the chosen behaviour leads to internal satisfaction (Hamid, Yahya, 2011; Meyer ir kt., 2010; Gregory ir kt., 2010; Turnbull, 2005). In the dissemination of values in the management team, it is important to have a strong interrelationship between the team members. It depends on the ability of the management team members to create a system of values. The value is closely related to the search of the meaning of human life and its ultimate purpose. The management team ought to demonstrate a moral commitment, understood as selfidentification with the goals and organisational values.

J. Albrechtas (2005), P. R. Scholtes et al. (2003), W. Bennis, B. Nanus (1998) argue that there has to be a clearly defined individual and joint responsibility of the management team members and clearly distributed areas of their responsibilities. The most important thing is to cherish respect, mutual understanding, and responsibility. The members must assume responsibility for respective decisions and to use efficient ways of activity. The leadership responsibility ought to be shared between all the members. Active participation of the management team members in decision making increases their responsibility, gives more energy and desire to implement the goals set by themselves, and helps to better understand the meaning of the work being dome. The responsibility for decision making of each manager, independently on the level of management in the company, "melts" in the efficient (or inefficient) activity of the management team.

Effective communication between the management team members is a must. The members of the management team commit themselves to open and honest communication. Objective assessment of the activity of each management team member and mutual trust is a necessary condition for cooperation, as only then the ideas and alternatives are freely expressed (Loureiro et al., 2009; Teresevičienė, Gedvilienè, 2003; Menshikov et al., 2017). The roles performed by the team leader are related to the leader's relationships with the team members, which should be based on the humaneness principles. To have effective interaction between the management team members, mutual assistance is emphasised as the assessment of abilities and opportunities, recognition of achievements and mistakes, and the result of motivation and the efforts made, of the possibilities to develop 
ENTREPRENEURSHIP AND SUSTAINABILITY ISSUES

ISSN 2345-0282 (online) http://jssidoi.org/jesi/

2017 Volume 5 Number 2 (December)

http://doi.org/10.9770/jesi.2017.5.2(4)

competences and the self-realisation. Only good and strong interrelations between the management team members create a synergistic effect, therefore, the company has to improve its communication processes.

When looking for the best decision, small conflicts often occur in the management team. Due to them, one can make the right decisions and to create a communication-friendly atmosphere. To reduce the number of conflicts, the psychological climate in the management team is improved. The best outcome of the conflict resolution is openness, reduction of tension, normalisation of relations, and increasing confidence (Komskienè, Birbalas, 2013; Ivančikaitè-Ustinovienė, 2009; Kvedaravičius, 2006; Ignatjeva et al, 2017).

In order to resolve conflicts more effectively, one first needs to identify open and hidden conflicts between the members of the company. The willingness and the ability of the team leader to successfully control his own and the team members' behaviour has a huge practical and economic value. The members of the management team have to share not only the achievements, but also the bitterness of defeats.

The theoretical complex of the elements necesssary for the management team development, based on the systemic analysis of scientific literature, is presented in Figure 1. The complex of the elements of the management team development is understood as a construct of the team understanding and special efforts of the team members.

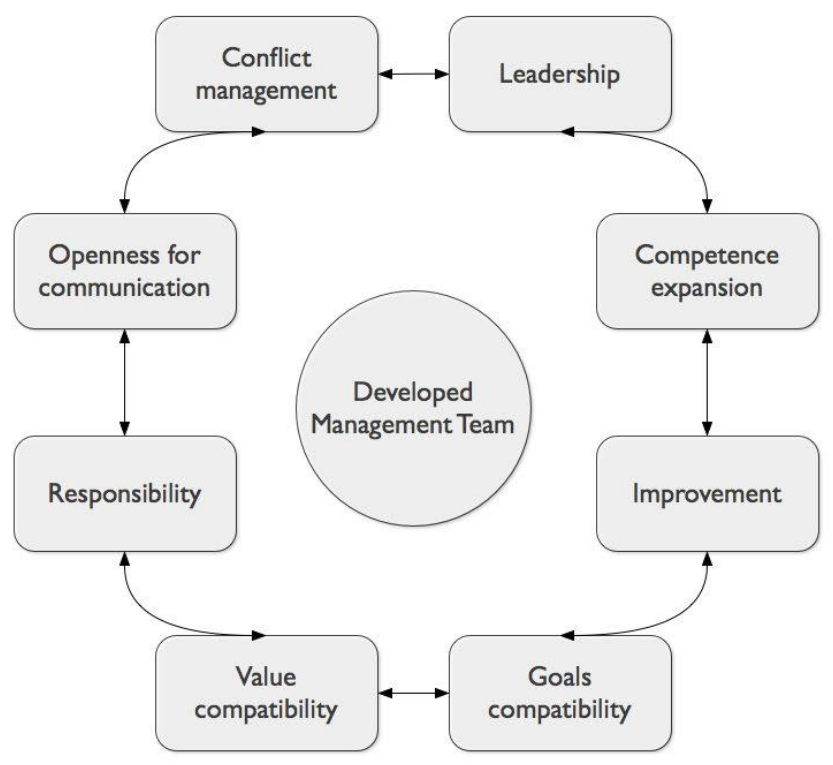

Figure 1. A theoretical model of the management team development

To summarise the above-discussed opportunities of the management team development, one can argue that management teams, being open, develop their competences, reflect on their experiences, change the environment by expanding the opportunities for activity, and initiate qualitative changes in a team. Thus a possibility appears to more flexibly and accurately respond to the changes in the environment and the organisation itself. The developing team of managers enrich the intellectual resources of the organisation, as, when collaborating with collegues, the competences acquired by a team member become a joint asset of the company. Therefore, we argue that the management team can develop when: it has a leader; the selected team members have additional competences and a great desire for improvement and leadership; when the activity is based on matching goals and harmonised values and on common and individual responsibility; and when the team is able to constructively resolve conflicts. By developing in accordance with those elements, the management team is maturing. 


\section{Research methods}

The research was conducted in a medium-sized furniture manufacturing company in Klaipeda region. The main buyer of the company's products is the Swedish concern Ikea.

The methodology. The aim of the research was to establish the feasibility of the management team development in a manufacturing company. As the disclosure of the phenomenon required an in-depth approach to the problem, qualitative research was chosen. A qualitative method allows the researcher to focus on the individual experience of the investigated subject which best reveals the subjective reality. Most importantly, qualitative research enables the researcher to more flexibly obtain exhaustive data and provides him with better opportunities to formulate the main conclusions of the research, based on the real-life entrepreneurial experience. The qualitative research sought to find out each manager's of the team subjective understanding of the development experience.

The data collection methods was a semi-structured interview to find out how the management team members behaved in different management situations and what development opportunities existed at the individual and team levels. The questionnaire included the informants' demographic data (age, education, and work experience) and the questions related to the eight main elements of the management team development. The data were recorded by a voice recorder. The recorded interviews were later transcribed, the keywords marked, and the environment was described as much in detail as possible; moreover, the emotions of the respondents were observed. During the research, we sought to keep the question formulation and the process of the interview of each informant uniform, as the same phenomenn was investigated.

Table 1. Demographic data of the informants

\begin{tabular}{|c|c|c|c|c|c|c|c|c|}
\hline \multirow{2}{*}{$\begin{array}{c}\text { Level of } \\
\text { management }\end{array}$} & \multicolumn{3}{|c|}{ Age (in years) } & \multicolumn{2}{|c|}{ Education } & \multicolumn{3}{|c|}{ Work experience (in years) } \\
\hline & $25-35$ & $35-45$ & $>45$ & Higher & Higher non-university & $5-10$ & $10-15$ & $>15$ \\
\hline MIDLE & 1 & 1 & & 2 & & 1 & 1 & \\
\hline
\end{tabular}

The data processing method was a content analysis method. The method is used to analyse the answers to the questions, to select certain meaningful units from the text, to calculate the frequency of their use, etc. (Kardelis, 2005; Tidikis, 2003). The method is divided into stages: 1) reading of the text in accordance with identified categories; 2) the division of the category content into subcategories; 3) interpretation of the categories and subcategories and justification by the text. In the analysis of the obtained resarch data, one looks for meaningful units that would reflect different aspects of the informants' experience and views related to the research object. The empirical indicators (statements) were grouped into sub-categories by notional similarity and calculated.

Selection of interviewees. In the research, a criterion-based selection was used, when the informants were selected in accordance with a certain researcher-established criterion (Rupšienė, 2007). The research participants were selected, based on the following criteria: 1) the manager's competence; 2) the manager's work experience (no less than 5 years); 3) a full-time position. The informants and their demographic data: the research participants included representatives of all management levels, including 2 top-level, 2 middle-level, and 4 low-level managers.

\section{Analysis of the findings}

On completion of the qualitative reseach in accordance with the compiled questionnaire, which sought to identify the behaviour of the management team members in management situations and the possibilities of the team development, meaningful statements were selected from the managers' answers and the frequency of their use was calculated. The summarised research findings are presented in Table 2. 
Table 2. The findings of the qualitative research

\begin{tabular}{|ll|l|}
\hline \multicolumn{2}{|c|}{ ELEMENTS } & \multicolumn{1}{|c|}{ SUBCATEGORIES AND NUMBER OF STATEMENTS } \\
\hline 1. & Leadership & $\begin{array}{l}\text { Be able to hear (10 statements); be able to constrain the members to take care of their matters (9 statements); } \\
\text { to show example (9 statements); be vigorous (8 statements); to cope with emotions (8 statements); have own } \\
\text { opinion (8 statements); don't be afraid of other opinions (5 statements); to initiate the development (5 } \\
\text { statements). }\end{array}$ \\
\hline 2. & $\begin{array}{l}\text { Competence } \\
\text { expansion }\end{array}$ & $\begin{array}{l}\text { New roles (15 statements); additional skills (12 statements); adjustment of features (10 statements); to seek a } \\
\text { career (8 statements). }\end{array}$ \\
\hline 3. & Improvement & $\begin{array}{l}\text { Important position (10 statements); increased responsibility (10 statements); self-confidence; appreciation (10 } \\
\text { statements); professional sophistication (6 statements); self-realisation (5 statements); }\end{array}$ \\
\hline 4. & $\begin{array}{l}\text { Goals } \\
\text { compatibility }\end{array}$ & $\begin{array}{l}\text { Purpose oriented goals (60 statements); realised goals (19 statements); long-term goals (13 statements); goals } \\
\text { for giving sense to subsistence (5 statements). }\end{array}$ \\
\hline 5. & $\begin{array}{l}\text { Value } \\
\text { compatibility }\end{array}$ & $\begin{array}{l}\text { The most important individual values (22 statements); manager's responsibility for spread of values (19 } \\
\text { statements); company's system of values under construction (15 statements); identification of the company } \\
\text { values with the values of employee (6 statements); }\end{array}$ \\
\hline 6. & Responsibility & $\begin{array}{l}\text { Manager-leader is the delegate of powers (19 statements); monitoring of responsibility (18 statements); limits } \\
\text { of responsibility (5 statements). }\end{array}$ \\
\hline 7. & $\begin{array}{l}\text { Openness for } \\
\text { communication }\end{array}$ & $\begin{array}{l}\text { Effective communication between team members (37 statements); empathy (17 statements); correlation of the } \\
\text { members (10 statements); constrictive relations (8 statements). }\end{array}$ \\
\hline 8. & $\begin{array}{l}\text { Conflict } \\
\text { management }\end{array}$ & $\begin{array}{l}\text { Often critical situations (28 statements); effective solutions (17 statements); certified methods of conflict } \\
\text { solution (15 statements); rapid solutions (10 statements); compromises (7 statements). }\end{array}$ \\
\hline
\end{tabular}

1. A management team needs a leader. The team leader's status makes an impact on the activity of all the team members. The management team leaders are empathetic, communicative, and able to take care of the remaining team members. As proved by the research findings, the leadership potential of the company managers was not sufficient, and that frequently became a serious barrier to further development of the team. The manager-leader has to match the capabilities of each individual member with the requirements set for them, given the strengths and weaknesses of each member.

2. The members of the management team seek to obtain additional competences. The research findings suggested that good financial reward was the most important thing for the team members. Even though the managers understood that in the present-day reality there were constant changes in the environment, their resolution to improve themselves was insufficient. It is necessary for the management team members to understand the personality improvement through individual needs, given the objectively limited possibilities. The management team brought together managers with different competences and different attitudes who were consciously pursuing the common goals of the company, who interacted in decision-making, and assumed responsibility for the manufactured product or service.

3. The striving of the management team members for excellence and a strong desire to be a leader. The management team members in the investigated company were communicative and ambitious executives (team members), planning to work in a desired position and seeking for a high status. The managers were well aware and appreciated the importance of will-power. Some of the management team members were worried about their future in the organisation. The statements illustrated the self-realisation aspect when the professional activity became an integral part of their identity. It could also be associated with the specialty idealisation which was undoubtedly caused by the pleasant feelings related to a managerial job. The attitude was evidently presupposed by a permanent pursuit to be the best, the leader, and win at all costs. The needs of the management team members activated the internal forces of a person and unconsciously awakened his activity. That was the need for success and achievement, the desire to do for the team all that one was able to.

4. The management team sought the compatibility of the company and personal goals. In the context of the present research findings, a career was defined as the pursuit of the managerial goals and satisfaction of personal ambitions. That suggested that a clear understanding of the goals mainly resulted in their successful realisation. 
The managers found the goal realisation to be complex and problematic, as it was necessary to find a trade-off between professional aspirations. There might have been a shortage of knowledge and skills. The team members understood professional development as a way of the life goals implementation leading to a successful career and material well-being. Frequent dimensions of the informants were a good job, good income, and a high social status. The activity of the management team members had to be coordinated and harmoniously focused on the pursuit of the corporate goals and the implementation of strategic plans. The management team members made decisions together, planned their implementation together, and were interested in the pursuit of common goals.

5.The compatibility of the members' values sought by the management team. As suggested by the research findings, the management team members pursued their values, and that was their direct development dimension. The following values were identified: sensitivity, goodness, caring, a wish to help, and tolerance. The conditions that formed in the interaction of the management team member with the environment formed a favourable context for the development of values. The analysis of individual indicators led to the conclusion that some members of the team felt a lack of economic and (or) spritual values. Those informants related their wishes and plans to the finding of meaning. The development of values of the management team members is especially topical as it predetermines the values that the team members justify their goals with and the conceptions that guide them in decision making.

6. All the management team members sought individual and shared responsibility. As proved by the qualitative research, most of the informants unambiguously advocated the sovereignty of the team members and the harmonisation of the powers and responsibilities. The empowered members of the team assumed responsibility for the efficient use of resources and the pursuit of an appropriate result. By reflecting, the team leader could evaluate how well the team members were prepared to assume responsibility for the roles assigned to them and how conscious their perception of the assumed responsibility was. The team members' personal responsibility had to be permanently strengthened, as it was the basis of overall management.

7. The aspiration of the management team members to openly communicate and collaborate. The research findings proved the informants' efforts and the ability to empathise with other person's feelings and their state. Empathy is a necessary element of all the management team members' communicative abilities that leads to open and sincere communication. The disharmony between the team and personal relationships means a mismatch between the personal goals and the ability of the team to satisfy them. The management team has to collaborate and to exchange information, knowledge, and experience both among themselves and with other staff members. Each member of the management team has to understand another person's situation, feelings, and motives.

8. The management team seeks to constructively resolve conflicts. The findings of the research proved that the members of the investigated management team were best at the resolution of the conflicts arising due to different ideas and preconceptions, as well as due to the experience, reflection, and meta-cognition. The attitudes of some informants suggested their gratitude and indebtedness to their colleagues for their moral support in conflict resolution. For the effective functioning of a management team, a positive conflict is beneficial, since it promotes openness, the reduction of tension, normalisation of relations, and increased confidence. Successful use of selfregulation skills in conflict resolution can help to handle day-to-day business problems more efficiently and improve the performance of the company.

To sum up the findings of the conducted qualitative research, we argue that the management team's leader must encourage each member of the team to look for the meaning of development (meaning-oriented goals: 60 statements), i. e. the identification of one's own strengths and weaknesses in development in order to effectively function in professional activity. It is necessary to create appropriate conditions for the management team to develop by communicating in a defined and/or chosen direction (effective communication of team members: 37 statements). Particularly great attention ought to be paid to the development of team members in a crisis situation (frequent modeling of emergency situations: 28 statements). Crises emerge due to the lack of knowledge how to 
ENTREPRENEURSHIP AND SUSTAINABILITY ISSUES

ISSN 2345-0282 (online) http://jssidoi.org/jesi/

2017 Volume 5 Number 2 (December)

http://doi.org/10.9770/jesi.2017.5.2(4)

behave in a newly encountered situation. Therefore, management teams members have to develop: critical thinking, the ability to justify decisions, application of the monitoring possibilities, problem identification possibilities, empathetic experience, and conflict management abilities.

\section{Conclusions}

The development of the management team is an artificially natural process of the socio-cultural system in which the internal qualitative potential is acquired by the team members' mastering of the new and improving of the old competences when seeking to more effectively work in the company. The set of elements of the management team development, based on the analysis of scientific literature, helps the management team to timely respond to the changes in the environment, makes them flexible, and requires continuous development in order to achieve efficiency. The participation of the management team in a development programme enables the development of the team members as personalities and as professionals: in that way, conditions are created to increase their performance first at the individual, and then at the team level. The development of the management team focuses on greater future oportunities, aspirations, and goals.

Upon conducting qualitative research in a furniture manufacturing company - a semi-structured interview (8 informants), we can propose the guidelines for the management team development: to enacourage all the member of the management team to become leaders; to identify the goals of the personality and the competence development; to find out which competences each member wants to improve and to allow them to undertake additional activities that would enable the improvement of those competences; to set the operational goals for the members which would also allow (help) them to pursue their personal goals; to coordinate the values of the organisation and the team members on the basis of needs, when the need for self-realisation prevail over the hierarchy; to give more responsibility to the team members who wish and seek it; and to authorise each member of the team to resolve conflicts independently.

It is necessary to make not only the head of the team - its leader, but also the team members be interested in identifying the hindrances that interfere with their individual and team development and constantly search for new opportunities to disclose their inner potential. Only when developing in such a way the managers at all levels of the company can function as one harmonious team of managers pursuing a common goal: the development of the managers, the management team, and the potential of a manufacturing company.

\section{References}

Albrechtas, J. 2005. Asmenybe ir karjera [Personality and career]. Vilnius: Naujoji matrica.

Beniušienè, I.; Vveinhardt, J.; Merkys, G.; Dromantas, M. 2005. Komandinio darbo ir organizacijos klimato sąryšio ypatumai [Peculiarities of interralation between teamwork and organization climate], Socialiniai tyrimai / Social Research 1 (5): 38-45.

Bennis, W.; Nanus, B. 1998. Lyderiai: atsakomybès strategija [Leaders: responsibility strategy]. Vilnius: Algarvè.

Diska V.; Marčinskas, A. 2013. Aukščiausio lygio vadovų komandų vaidmuo ir poveikis organizacijų veiklai žiniomis grindžiamos visuomenès iššūkių kontekste [Role of the highest hierachal level executives and their impact on organization performace in knowledge based challenges' context], Informacijos mokslai 66: 64-77.

Dlugoborskytė, V.; Norvilaitè, V.; Petraitè, M. 2015. Creativity and innovation management: team performance peculiarities, Entrepreneurship and Sustainability Issues 3(1): 25-39. https://doi.org/10.9770/jesi.2015.3.1(2)T

Drucker, P. F. 2009. Drukerio mokymo pagrindai [Basics of Drucker's teaching]. Kaunas: UAB "Dakra“.

Gregory, B. T.; Albritton, M. D., \& Osmonbekov, T. (2010). The Mediating Role of Psychological Empowerment on the Relationships between P-O Fit, Job Satisfaction, and In-role Performance, Journal of Business and Psychology 25(4): 639-647. https://doi.org/10.1007/s10869-010-9156-7 
Hamid, S. N. A.; Yahya, K. K. 2011. Relationship Between Person - Job Fit and Person - Organization Fit on Employees' Work Engagement: A Study among Engineers in Semiconductor Companies in Malaysia. Annual conference on Innovations in Business and Management, London, 6-9 June, UK: 1-30.

Hirschfeld, R.; Jordan, H.; Field, S.; Giles, F. W.; Armenakis, A. 2006. Becoming Team Players: Team Members’ Mastery of Teamwork Knowledge as a Predictor of Team Task Proficiency and Observed Teamwork Effectiveness, Journal of Applied Psychology 91(2): 467474. https://doi.org/10.1037/0021-9010.91.2.467

Ignatjeva, S.; Volosnikova, L.; Efimova, G. 2017. Assessment of inclusive educational space in higher education institution, Journal of Security and Sustainability Issues 7(1): 123-132. https://doi.org/10.9770/jssi.2017.7.1(10)

Yuen, C. 2004. Good characteristics, communication and reward systems, and managerial propensity to create budgetary control, Managerial Auditing Journal 19: 517-532. https://doi.org/10.1108/02686900410530529

Ivančikaitė-Ustinovienè, V. 2009. Komandinio darbo efektyvumo rodikliai švietimo ir verslo organizacijose [Teamwork efficiency indicators in education and business organizations]. Vilnius: VPU.

Jezerskyte, E.; Žydžiūnaite, V. 2005. Comparing Teamwork Comperencies of The School Administration and Educatiors: The Aspects of Groupthink (Avoidance) and Social Loafing, Social Sciences 3(49): 87-95. http://etalpykla.lituanistikadb.lt/fedora/get/LT-LDB0001:J.04 2005 1367157552498/DS.002.1.01.ARTIC

Kardelis, K. 2005. Moksliniu tyrimu metodologija ir metodai [Methodology and methods of research]. Trečias leidimas. Šiauliai: Lucilijus.

Kasiulis, J.; Barvydienè, V. 2004. Vadovavimo psichologija [Psyhology of managing]. 3-ioji laida. Kaunas: Technologija.

Komskienè, D.; Birbalas, I. 2013. Konfliktų raiška ir sprendimo būdai sporto organizacijoje [Conflicts` and their resolution in sport organization]. Mokslas ir praktika: aktualijos ir perspektyvos. Kaunas: Lietuvos sporto universitetas, 178-186.

Kvedaravičius, J. 2006. Organizacijų vystymosi vadyba [Management of organizations 'development]. Kaunas: VDU.

Loureiro, I.; Sherriff, N.; Davies, KJ. 2009. Developing public health competencies trought building a problem-based learning project. Journal of Public Health 17: 417-424.

Meyer, J. P.; Hecht, T. D.; Gill, H.; Toplonytsky, L. 2010. Person - Organization fit and employee commitment under conditions of organizational change: a longitudital study, Journal of vocational behavior 76: 458-473.

Menshikov, V.; Lavrinenko, O.; Sinica, L.; Simakhova, A. 2017. Network capital phenomenon and its posibilities under the influence of development of information and communication technologies, Journal of Security and Sustainability Issues 6(4): 585604. https://doi.org/10.9770/jssi.2017.6.4.(5)

Misevičius, V., Urbonienė, R. 2006 Dalykinio bendravimo pagrindai [Basics of business communication]. Šiauliai: Šiaulių universiteto leidykla.

Raižienè, S., Endriulaitienė, A. 2007. Organizacinè psichologija: komandu formavimo principai [Organizational psyhology: principles of teams formation]. Kaunas: VDU.

Robbins, S .P. 2003. Organizational behaviour concepts, controversies, application. 8th ed. New Jersey: Prentice-hall International.

Rupšienè, L. 2007. Kokybinio tyrimo duomeny rinkimo metodologija [Metodology of qualitative collection of data]. Klaipėda: KU leidykla.

Savanevičienė, A.; Stukaitè, D.; Šilingienè, V. 2008. Development of strategic individual competences. Inžinerinė ekonomika-Engineering economics 3: 81-88.

Scholtes, P.R.; Joiner, B. L.; Streibel, B. J. 2003. The Team Handbook. Oriel Incorporated.

Smith, G. P. 2006. United We Stand. Divided We Fall. Available on the Internet: http://chartcourse.blogspot.com

Staniulienė, S. 2008. Vadovų galių naudojimas Lietuvos įmonėse jų pavaldinių požiūriu [Managers‘ use of different powers in Lithuanian companies from the viewpoint of their subordinates], Organizaciju vadyba: sisteminiai tyrimai 48: 121 - 137.

Teresevičienè, M.; Gedvilienė G. 2003. Mokymasis grupèse ir asmenybès kaita [Learning in groups and change of personality]. Kaunas: Vytauto didžiojo universitetas. 
ENTREPRENEURSHIP AND SUSTAINABILITY ISSUES

ISSN 2345-0282 (online) http://jssidoi.org/jesi/

2017 Volume 5 Number 2 (December)

http://doi.org/10.9770/jesi.2017.5.2(4)

Tidikis R. 2003. Socialinių mokslu tyrimu metodologija [Methodology of social sciences]. Vilnius: Lietuvos teisès universiteto Leidybos centras.

Tuckman, B. 1965. Developmental sequence in small groups, Psychological Bulletin 63: 384-399.

Turnbull, B. 2005. Evaluating school-based management: A tool for team self-review, International Journal of Leadership in Education https://doi.org/10.1080/1360312042000255871

West, M. A. 2012. Effective Teamwork: Practical Lessons from Organizational Research. Wiley-Blackwell.

Zakarevičius, P. 2003. Pokyčiai organizacijose: priežastys, valdymas, pasekmès [Changes in organizations: reasons, management, consequences]. Kaunas: Vytauto Didžiojo universitetas.

Žydžiūnaitè, A. 2003. Komandinio darbo kompetenciju edukacine diagnostika ir ju vystymo, rengiant slaugytojus, pagrindimas [Educological diagnostic of teamwork competences and their development in education of nurces]. Daktaro disertacija. Edukologijos mokslai (07). Kaunas: Kauno Technologijos universitetas.

Algirdas GIEDRAITIS is a associate professor of the Department of Management of the Faculty of Social Sciences of Klaipeda University, Doctor of Social Sciences. Currently, he is actively interested in management ergonomics, production and personnel management.

ORCID ID: orcid.org/0000-0001-6813-2980

Rimantas STAŠYS is the head of the Department of Management of the Faculty of Social Sciences of Klaipeda University, a professor of social sciences. Currently, he is actively interested in healthcare management and the development of a new product.

ORCID ID: orcid.org/0000-0002-3991-5940

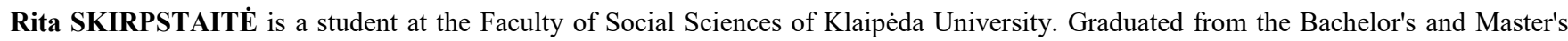
degree from the Vilnius University (specialization: Banking and Applied Macroeconomics). Currently, he is actively interested in management and intends to study management in doctoral studies.

ORCID ID: orcid.org/0000-0002-4422-268X

Copyright (C) 2017 by author(s) and VsI Entrepreneurship and Sustainability Center

This work is licensed under the Creative Commons Attribution International License (CC BY).

http://creativecommons.org/licenses/by/4.0/

c) (i) Open Access 